\title{
Evaluation of neem-based nanoformulations as alternative to control fall armyworm
}

\author{
Avaliação de nanoformulações à base de nim como alternativa \\ para o controle da lagarta do cartucho
}

\author{
Angelina Maria Marcomini Giongo ${ }^{1 *}$, José Djair Vendramim¹, Moacir Rossi Forim²
}

\author{
${ }^{1}$ Escola Superior de Agricultura Luiz de Queiroz/ESALQ, Piracicaba, SP, Brasil \\ 2Universidade Federal de São Carlos/UFSCAR, São Carlos, SP, Brasil \\ *Corresponding autor: ammarcomini@yahoo.com.br \\ Received in august 19, 2015 and aproved in november 16, 2015
}

\begin{abstract}
Neem (Azadirachta indica A. Juss.) based insecticides are efficient for the control of various pest species, but their low residual effect and the lack of standardized formulations are problems for field use. Nanoformulations of neem in colloidal suspension or powder, containing the polymers poly ( $\varepsilon$-caprolactone) (PCL), poly ( $\beta$-hidroxibutirate) (PHB) or poly (methyl methacrylate) (PMMA), in capsules or spheres, were developed in order to reduce biodegradation of the active neem compounds and improve their residual effect. Corn leaves treated with the nanoformulations were offered to first instar larvae of fall armyworm during 10 days, observing mortality and larval weight and comparing it to a commercial neem oil and negative controls. The residual effect of the four most efficient nanoformulations was evaluated at 1, 3 and 7 days after spraying (DAS). Feeding preference tests with dual-choice (treatment vs. control) were performed with corn leaf disks at 1, 3 and 7 after DAS, and a preference index was determined 24 hours after larvae feeding on the disks. Some nanoformulations caused mortality up to 3 DAS and sublethal effects up to 7 DAS, but none outperformed the residual effect of commercial neem oil. All treatments showed phagodeterrence at 1 DAS, but this was lost over time. The short duration of the nanoformulations' efficacy suggests that there was little or no release of neem by the nanoparticles, so more studies are needed to improve the release kinetics of the nanoformulated products.
\end{abstract}

Index terms: Azadirachta indica; Spodoptera frugiperda; polymeric nanoparticles; controlled-release formulations.

\begin{abstract}
RESUMO
Inseticidas à base de nim (Azadirachta indica A. Juss.) são eficientes para controle de várias espécies de pragas, porém o baixo efeito residual e a falta de padronização das formulações são um problema para uso em campo. Nanoformulações de nim em suspensão coloidal e em

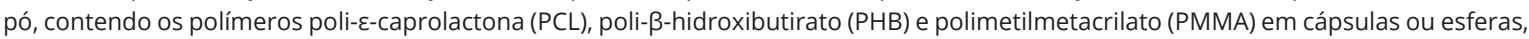
foram desenvolvidas, a fim de reduzir a biodegradação dos compostos ativos e melhorar seu efeito residual. Folhas de milho tratadas com as nanoformulações foram oferecidas a lagartas de primeiro ínstar de lagarta do cartucho durante 10 dias, observando-se a mortalidade e o peso larval e comparando com um óleo comercial de nim e controles negativos. O efeito residual das quatro nanoformulações mais eficientes foi avaliado aos 1, 3 e 7 dias, após a pulverização (DAP). Testes de preferência alimentar com dupla escolha (tratamento vs. controle) foram realizados com discos de folhas de milho aos 1, 3 e 7 DAP, e um índice de preferência foi determinado 24 horas após as lagartas se alimentarem nos discos foliares. Algumas nanoformulações causaram mortalidade até 3 DAP e efeitos subletais até 7 DAP, mas nenhuma superou o efeito residual do óleo comercial de nim. Todos os tratamentos apresentaram fagodeterrência em 1 DAP, mas esta foi perdida ao longo do tempo. A curta duração da eficiência das nanoformulações indica que houve pouca ou nenhuma liberação dos compostos das nanopartículas; assim, mais estudos são necessários para melhorar a cinética de liberação dos produtos nanoformulados.
\end{abstract}

Termos para indexação: Azadirachta indica; Spodoptera frugiperda; nanopartículas poliméricas; formulações de liberação controlada.

\section{INTRODUCTION}

The neem tree, Azadirachta indica A. Juss., is very promising for the control of many insect species, including Spodoptera frugiperda (J. E. Smith) (Lepidoptera: Noctuidae) (Campos; Boiça Junior, 2012; Lima et al., 2010; Roel et al., 2010; Viana; Prates; Ribeiro, 2007), a very important corn pest in Brazil (Cruz; Monteiro,
2004). The effects of neem oils and extracts on insects are due to the presence of large quantities of limonoids, among which azadirachtin is the most complex and potent (Mordue (Luntz); Nisbet, 2000). Azadirachtin has strong antifeedant activity due to its effect on chemoreceptors; it affects ecdysteroid and juvenile hormone titers by blocking morphogenetic peptide hormone release, resulting in growth 
and molting aberrations, and it has direct histopathological effects on insect muscles, fat body, and gut epithelial cells (Mordue (Luntz); Blackwell, 1993). Therefore, neem acts as an insect growth regulator and as a feeding and oviposition deterrent (Mordue (Luntz); Nisbet, 2000; Isman, 2006).

One problem with the use of neem on a large scale is the high photosensitivity of azadirachtin, which breaks down or isomerizes under sunlight; thus, neem has low residual effect under field conditions (Riyajan; Sakdapipanich, 2009). Moreover, the lack of standardization and quality control in neem-based formulations produced in Brazil affect the reproducibility of the insecticide effect (Forim et al., 2010).

The use of nanotechnology in agriculture has been studied in recent years, including the development of controlled-release formulations of insecticides by polymeric encapsulation (Perlatti et al., 2013; Das et al., 2014). There are some studies concerning botanical insecticides encapsulated using micro and nanoparticle systems (Oliveira et al., 2014). Encapsulation of neem oil and extracts into membranes or polymeric walls may improve their efficiency, since they protect the active ingredients and allow controlled release, preventing the loss of volatile compounds and increasing their stability in the environment (Riyajan; Sakdapipanich, 2009). Polymers like poly ( $\varepsilon$-caprolactone) (PCL), poly ( $\beta$-hidroxibutirate) (PHB) (Rosa; Penteado; Calil, 2000), poly [ $\beta(1,4)-2$-amino-2-deoxy-D-glusose] (chitosan) (Li et al., 2012) and poly (methyl methacrylate) (PMMA) (Chan et al., 2009) can be used as encapsulants. The degradation rate of these polymers can be adjusted, for example, by variations in their composition, the molecular weight of the polymer, and nanoparticle preparation methods (Ré; Rodrigues, 2006). Therefore, the aim of this work was to evaluate the insecticidal and residual effects of neem-based nanoformulations with polymers as encapsulant agents against $S$. frugiperda larvae.

\section{MATERIAL AND METHODS}

\section{Insects and plants}

The fall armyworm larvae were reared in the laboratory (temperature: $25 \pm 3{ }^{\circ} \mathrm{C}$, relative humidity: $60 \pm 10 \%$, photophase: 14 hours) on an artificial diet (Burton; Perkins, 1972). Corn plants (hybrid 2B710, Dow AgroSciences) were grown in a greenhouse in plastic pots ( $2 \mathrm{~L}$ ), four to six plants per pot, and thirty to forty-day-old plants were used for the bioassays.

\section{Nanoformulations}

The neem nanoformulations were composed of neem seed kernel extract, obtained by solvent percolation in ethanol on a magnetic stirrer, and/or commercial neem oil (Organic Neem, Dalquim Ind. Com. Ltd.). The polymers evaluated were poly( $\varepsilon$-caprolactone) (PCL) (Aldrich) and poly(ßhidroxibutirate) (PHB) (Fluka) at 0.25, 0.5 and $0.75 \mathrm{~g}$, and poly(methylmethacrylate) (PMMA) (Aldrich) at $0.25 \mathrm{~g}$. Two kinds of nanoparticles were prepared: nanocapsules (NC) composed of a polymeric layer coating a mixture of neem commercial oil and neem seed kernel extract, and nanospheres (NS) composed of a polymeric matrix containing only neem seed kernel extract. The formulations were obtained as colloidal suspensions by the method of interfacial preformed polymers deposition (Fessi et al., 1989), and as powders, by spray drying the colloidal suspensions using a Büchi B290 Spray Dryer with Aerosil ${ }^{\circledR} 200$ as a drying support. Nanoformulations without neem were included to be tested as negative controls (Table 1).

\section{Lethal concentration $50\left(\mathrm{LC}_{50}\right)$ of commercial neem oil}

The commercial neem oil to be used as a positive control was sprayed on corn plants $(15 \mathrm{~mL}$ per pot) in concentrations ranging from 0.5 to $4.0 \%$, diluted in distilled water and surfactant (Extravon 0.2\%), in order to estimate de $\mathrm{LC}_{50}$. The azadirachtin content of the product was determined using the HPLC-MS/MS method according Forim et al. (2010). In the next morning after spraying, leaf sections were cut and placed in glass tubes $(2.5 \mathrm{~cm} \times 8.5 \mathrm{~cm})$ and one first instar larva (48-hour-old) was placed in each tube, which were then capped with cotton and maintained in the laboratory (temperature: $25 \pm 3^{\circ} \mathrm{C}$, relative humidity: $60 \pm 10 \%$, photophase: 14 hours). The experimental design was completely randomized and four replicates of 20 larvae per treatment were performed. Larval mortality was assessed daily, when leaf sections were replaced. The mortality after six days was used for the $\mathrm{LC}_{50}$ estimate.

\section{Screening of nanoformulations}

The nanoformulations were divided into groups and tested in five bioassays in comparison with a positive control (commercial neem oil), negative controls (nanoformulations without neem) and water. The solutions were prepared in distilled water with surfactant (Extravon $0.2 \%$ ). The azadirachtin concentration $(\mathrm{mg} / \mathrm{L}$ ) of all nanoformulations (both neem oil and extracts) was adjusted by dilution to be correspondent to the $\mathrm{LC}_{50}$ of commercial neem oil, obtained in the previous bioassay. Corn plants were sprayed with nanoformulations using the same procedure described above to estimate $\mathrm{LC}_{50}$ and maintained in the greenhouse. Larval mortality was assessed daily, when leaf sections were replaced. On the tenth day, the surviving larvae were weighed. The most 
efficient formulations were selected for residual effect and feeding preference tests.

\section{Residual effect}

The most efficient nanoformulations, commercial neem oil and water were applied to corn plants in the greenhouse at the concentration correspondent to the $\mathrm{LC}_{50}$ and offered to first instar larvae of fall armyworm at three different times starting from spraying: 1, 3 and 7 days after spraying (DAS), each one as a separate bioassay, to evaluate the residual effect. The procedures were the same as previously described. Four replicates with 15 larvae per treatment were performed. The parameters evaluated were larval mortality and weight of the surviving larvae after 10 days.

Table 1: Composition of nanoformulations in colloidal suspension or in powder evaluated against fall armyworm larvae.

\begin{tabular}{|c|c|}
\hline Nanoformulations & Description \\
\hline \multicolumn{2}{|r|}{ Formulations with neem } \\
\hline NC-PCL(0.25) & Nanocapsules PCL $(0.25 \mathrm{~g})+$ neem oil + neem extract + Tween ${ }^{\circledR} 80$ \\
\hline NC-PCL(0.50) & Nanocapsules PCL $(0.50 \mathrm{~g})+$ neem oil + neem extract + Tween ${ }^{\circledR} 80$ \\
\hline NC-PCL(0.75) & Nanocapsules PCL $(0.75 g)+$ neem oil + neem extract + Tween ${ }^{\circledR} 80$ \\
\hline $\mathrm{NC}-\mathrm{PHB}(0.25)$ & Nanocapsules PHB (0.25g) neem oil + neem extract + Tween ${ }^{\circledR} 80$ \\
\hline NC-PHB(0.50) & Nanocapsules PHB $(0.50 \mathrm{~g})+$ neem oil + neem extract + Tween ${ }^{\circledR} 80$ \\
\hline $\mathrm{NC}-\mathrm{PHB}(0.75)$ & Nanocapsules PHB $(0.75 \mathrm{~g})+$ neem oil + neem extract + Tween ${ }^{\circledR} 80$ \\
\hline NC-PMMA(0.25) & Nanocapsules PMMA $(0.25 \mathrm{~g})+$ neem oil + neem extract + Tween ${ }^{\circledR} 80$ \\
\hline NC-PCL(0.25)pva & $\begin{array}{c}\text { Nanocapsules PCL }(0.25 \mathrm{~g})+\text { neem oil }+ \text { neem extract + } \\
\text { poly (vinyl alcohol) }\end{array}$ \\
\hline NS-PCL(0.25) & Nanospheres PCL (0.25g) + neem extract + Tween ${ }^{\circledR} 80$ \\
\hline NS-PCL(0.50) & Nanospheres PCL $(0.50 \mathrm{~g})+$ neem extract + Tween ${ }^{\circledR} 80$ \\
\hline NS-PCL(0.75) & Nanospheres PCL $(0.75 g)+$ neem extract + Tween ${ }^{\circledR} 80$ \\
\hline NS-PHB(0.25) & Nanospheres PHB (0.25g) + neem extract + Tween ${ }^{\circledR} 80$ \\
\hline NS-PHB(0.50) & Nanospheres PHB $(0.50 \mathrm{~g})+$ neem extract + Tween ${ }^{\circledR} 80$ \\
\hline NS-PHB(0.75) & Nanospheres PHB $(0.75 g)+$ neem extract + Tween ${ }^{\circledR} 80$ \\
\hline NS-PMMA(0.25) & Nanospheres PMMA $(0.25 \mathrm{~g})+$ neem extract + Tween ${ }^{\circledR} 80$ \\
\hline NS-PCL(0.25)pva & $\begin{array}{l}\text { Nanospheres PCL }(0.25 g)+\text { neem extract + } \\
\text { poly (vinyl alcohol) }\end{array}$ \\
\hline \multicolumn{2}{|r|}{ Formulations without neem (negative controls) } \\
\hline NC-PCL(0.25)-NC & Nanocapsules PCL (0.25g) + Isodecil oleate + Tween ${ }^{\circledR} 80$ \\
\hline NC-PHB(0.25)-NC & Nanocapsules PHB (0.25g) + Isodecil oleate + Tween ${ }^{\circledR} 80$ \\
\hline NC-PMMA(0.25)-NC & Nanocapsules PMMA (0.25g) + Isodecil oleate + Tween ${ }^{\circledR} 80$ \\
\hline NS-PCL(0.25)-NC & Nanospheres PCL (0.25g) + Tween ${ }^{\circledR} 80$ \\
\hline NS-PHB(0.25)-NC & Nanospheres PHB (0.25g) + Tween ${ }^{\circledR} 80$ \\
\hline NS-PMMA(0.25)-NC & Nanospheres PMMA (0.25g) + Tween ${ }^{\circledR} 80$ \\
\hline
\end{tabular}

$\mathrm{NC}=$ nanocapsule, $\mathrm{NS}=$ nanosphere, $\mathrm{PCL}=$ poly $(\varepsilon$-caprolactone), $\mathrm{PHB}=$ poly (ß-hidroxibutirate), $\mathrm{PMMA}=$ poly $(\mathrm{methyl}$, methacrylate), $\mathrm{NC}=$ negative control, pva = poly (vinyl alcohol), $[\mathrm{S}]=$ suspension, $[\mathrm{P}]=$ powder. 


\section{Feeding preference}

Dual-choice bioassays (treatment $v s$. control) were carried out using corn plants treated with the most efficient nanoformulations. Leaf disks $\left(6.15 \mathrm{~cm}^{2}\right)$ obtained from corn leaves at 1, 3 and 7 DAS were used. Two leaf disks from each treatment and from the control were intercalated in a circular arena $(15 \mathrm{~cm}$-diameter Petri dishes with humidified plaster on the bottom). A third instar larvae was placed in each dish, and after 24 hours the remaining area of the leaf disks was measured using a leaf area meter (Li-Cor, model LI-3000A). The area consumed was calculated by the difference between the initial and final area. Bioassays were carried out individually for each treatment in comparison with control (water), and 20 replicates were performed for each treatment. As an aliquot, 10 leaf disks were measured and the mean was used as the initial area. A comparison of the area consumed between treatments was performed using a preference index (PI) (Kogan; Goeden, 1970): PI $=(2 \times T) /(C+T)$, where: $\mathrm{T}=$ consumed area in the treated leaf disk; $\mathrm{C}=$ consumed area in the control leaf disk. The treatment was considered neutral when $\mathrm{PI}=1$; not preferred (or phagodeterrent) when $\mathrm{PI}<1$ and preferred when $\mathrm{PI}>1$.

\section{Data analysis}

All bioassays were carried out in a completely randomized design. The $\mathrm{LC}_{50}$ was estimated using Probit analysis (Finney, 1971), with PoloPlus 1.0 software (Leora Software, 2003). The mortality data were analyzed using a generalized linear model, with the chi-square test $(p<0.05)$ and Tukey test for means comparison. The data on weight and leaf area consumed were analyzed by the Bartlett test to check variances in the homoscedasticity of the treatments and by the Shapiro-Wilk test to check the normal distribution of residuals. When these conditions were not met, the data were transformed by the Yeo-Johnson method (Yeo; Johnson, 2000). Analysis of variance was performed by the $\mathrm{F}$ test $(p<0.05)$, and means were compared by the Tukey test $(p<0.05)$. The analyses were performed with statistical software $\mathrm{R}$ 3.0.1 (R Development Core Team, 2013).

\section{RESULTS AND DISCUSSION}

\section{Lethal concentration $50\left(\mathrm{LC}_{50}\right)$ of a commercial neem oil}

The estimated $\mathrm{LC}_{50}$ of the commercial neem oil for first instar larvae of S. frugiperda was $0.64 \%$ when applied on corn plants in the greenhouse, corresponding to 3.87 mg azadirachtin/L (Table 2).

\section{Screening of nanoformulations}

In the five bioassays carried out with the nanoformulations containing $3.87 \mathrm{mg}$ azadirachtin/L (corresponding to the estimated $\mathrm{LC}_{50}$ for the commercial neem oil), none of them caused mortality similar to or greater than the commercial neem oil. In the first bioassay (Table 3), nanoformulations in colloidal suspension [S]NC-PMMA $(0.25)$ and [S]NS-PMMA $(0.25)$ caused the highest mortality, 48.75 and $45.00 \%$, respectively, and reduced larval weight. These same nanoformulations in powder did not differ from the negative controls. However, the suspensions were not more efficient than the commercial neem oil, Organic Neem $(100.00 \%)$ or its powder formulation, $[\mathrm{P}] \mathrm{ON}(75.00 \%)$.

In the second bioassay, only the nanoformulations [S]NC-PCL ( 0.75$)$ and [S]NC-PHB (0.25) caused mortality (45.00 and $42.50 \%$, respectively) similar to the Organic Neem (56.25\%) (Table 4). All nanoformulations reduced larval weight in comparison to the water-control, not differing from the neem commercial oil. No difference was observed between nanoformulation [S]NC-PCL (0.25)pva and the similar nanoformulation with Tween ${ }^{\circledR} 80$ [S]NC-PCL $(0.25)$. In the third bioassay these same nanoformulations were tested in powder. Only [P]NC-PCL $(0.25)$ pva caused significant mortality $(55.00 \%)$, but not greater than the Organic Neem $(86.25 \%)$. In this case, the powder nanoformulation with PVA differed from that containing Tween $^{\circledR} 80$. In relation to larval weight, only [P]NC-PHB $(0.25)$ differed from the controls and did not differ from the commercial neem oil. The nanoformulation [P]NC-PCL (0.75) also did not differ from the neem oil and differed from the water-control, but they did not differ from the nanoformulation without neem (negative control) (Table 4).

Table 2: Estimate of lethal concentration $50\left(\mathrm{CL}_{50}\right)$ and confidence interval of the commercial neem oil Organic Neem to fall armyworm larvae fed since first instar with corn leaves treated with the product, after six days.

\begin{tabular}{ccccc}
\hline $\begin{array}{c}\text { Number of } \\
\text { evaluated insects }\end{array}$ & Slope \pm SE & $\begin{array}{c}\mathrm{LC}_{50}(\% \text { c.p.) and Confidence } \\
\text { Interval (95\%) }\end{array}$ & $\chi^{2}$ & d.f. \\
\hline 480 & $2.048 \pm 0.304$ & $0.644(0.443-0.829)^{1}$ & 0.681 & 2 \\
\hline${ }^{1}$ Corresponding to $3.87(2.66-4.98)$ mg azadirachtin/L. & & &
\end{tabular}


Table 3: Mortality and weight ( \pm SE) of fall armyworm larvae fed since the first instar with corn leaves treated with neem nanoformulations, after 10 days (first bioassay).

\begin{tabular}{ccc}
\hline Treatment & Mortality (\%)* & Weight $(\mathrm{mg})^{\star}$ \\
\hline Water-control & $8.75 \pm 5.91 \mathrm{a}$ & $72.42 \pm 9.46 \mathrm{a}$ \\
{$[$ S]NC-PMMA(0.25)-NC } & $8.75 \pm 3.75 \mathrm{a}$ & $72.83 \pm 2.43 \mathrm{a}$ \\
{$[$ P]NS-PMMA(0.25)-NC } & $8.75 \pm 2.39 \mathrm{a}$ & $71.91 \pm 3.24 \mathrm{ab}$ \\
[P]NC-PMMA(0.25)-NC & $10.00 \pm 4.56 \mathrm{a}$ & $72.24 \pm 2.48 \mathrm{ab}$ \\
[S]NS-PMMA(0.25)-NC & $11.25 \pm 3.15 \mathrm{a}$ & $62.33 \pm 4.75 \mathrm{ab}$ \\
{$[$ P]NC-PMMA(0.25) } & $20.00 \pm 6.45 \mathrm{a}$ & $34.80 \pm 4.34 \mathrm{bc}$ \\
[P]NS-PMMA(0.25) & $26.25 \pm 5.54 \mathrm{a}$ & $43.68 \pm 2.59 \mathrm{abc}$ \\
[S]NS-PMMA(0.25) & $45.00 \pm 3.54 \mathrm{~b}$ & $16.07 \pm 1.46 \mathrm{~cd}$ \\
{$[$ S]NC-PMMA(0.25) } & $48.75 \pm 6.57 \mathrm{~b}$ & $11.32 \pm 2.01 \mathrm{~d}$ \\
{$[P] O N$} & $75.00 \pm 3.54 \mathrm{c}$ & $8.55 \pm 1.12 \mathrm{~d}$ \\
Organic Neem & $100.00 \pm 0.00 \mathrm{c}$ & --- \\
\hline $\mathrm{F}$ & - & 17.09 \\
$p$ & $<0.001$ & $<0.001$ \\
\hline
\end{tabular}

* Means followed by the same letter do not differ significantly by the Tukey test $(p<0.05)$.

$[\mathrm{S}]=$ colloidal suspension, $[\mathrm{P}]=$ powder, $\mathrm{NC}=$ nanocapsules, NS = nanospheres, $\mathrm{PMMA}=$ poly $($ methyl methacrylate $)$, NC = negative control, $\mathrm{ON}=$ Organic Neem.

None of the colloidal suspensions of nanospheres showed the same effect as Organic Neem in relation to mortality $(86.25 \%)$ in the fourth bioassay (Table 5), but five differed from water and negative controls: [S]NSPHB-0.25 (56.25\%), [S]NS-PHB- $0.50(53.75 \%)$, [S]NS$\operatorname{PCL}(0.25)(42.50 \%),[S] N S-P C L(0.75)(41.25 \%)$, and [S] NS-PCL(0.50) (40.00\%). The nanoformulation in colloidal suspension with Tween ${ }^{\circledR} 80(42.50 \%)$ was more efficient than the one with PVA (25.00\%). All nanoformulations caused significant decreases in larval weight (7.07 to $13.57 \mathrm{mg})$, similar to the commercial neem oil $(8.13 \mathrm{mg})$, differing from water and nanoformulations without neem. These same nanoformulations in powder, tested in the fifth bioassay, did not cause significant mortality or reduced weight (Table 5).

Rampelotti-Ferreira, Vendramim and Forim (2012) evaluated the effect of some nanoformulations on Tuta absoluta Meyrick (Lepidoptera: Gelechiidae); the highest mortality was obtained with suspensions and powdered PHB nanocapsules and PMMA nanospheres after 10 days of feeding on treated tomato leaves. Among these, only the nanoformulation of PMMA nanospheres in suspension also caused an effect on fall armyworm larvae in the present study ([S]NS-PMMA (0.25) (Table 3).

Some nanoformulations caused both mortality and lower weight gain. Correia et al. (2009) described morphologic changes in the midgut of third instar larvae of fall armyworm fed on corn leaves treated with neem $\left(\right.$ Neemseto $\left.^{\circledR}\right)$ at concentrations of 0.5 and $1.0 \%$, with epithelium degeneration and reduction of secretory activity. These changes caused by neem affected cell renovation and nutrient absorption, interfering with food conversion and causing low weight gain by the larvae.

The absence of an effect of nanoformulations without neem, used as negative controls, indicates that the materials used as inerts in the encapsulation process did not cause adverse effects on insects, and did not interfere with the action of neem. Nanoformulations with the polymers PCL, PHB, and PMMA, and with nanocapsules and nanospheres proved to be efficient, indicating that all these can be used for neem encapsulation. The fate of the polymers used in controlled-release formulations and their effects on the environment have to be considered, so the use of biodegradable polymers like PCL and PHB is desirable. 
Table 4: Mortality and weight ( \pm SE) of fall armyworm larvae fed since the first instar with corn leaves treated with neem nanoformulations in suspension (second bioassay) and in powder (third bioassay), after 10 days.

\begin{tabular}{|c|c|c|}
\hline Treatment & Mortality (\%)* & Weight $(\mathrm{mg})^{*}$ \\
\hline [S]NC-PCL(0.25)pva & $16.25 \pm 3.15 a$ & $10.26 \pm 0.91 c$ \\
\hline$[\mathrm{S}] \mathrm{NC}-\mathrm{PHB}(0.75)$ & $16.25 \pm 3.75 a$ & $12.73 \pm 0.86 b$ \\
\hline [S]NC-PCL(0.25)-NC & $17.50 \pm 4.79 a$ & $24.54 \pm 0.36 a b$ \\
\hline Water-control & $18.75 \pm 2.39 a$ & $39.77 \pm 3.85 a$ \\
\hline [S]NC-PHB(0.25)-NC & $20.00 \pm 4.08 a$ & $26.58 \pm 2.04 a$ \\
\hline [S]NC-PCL(0.25) & $25.00 \pm 4.56 a$ & $12.01 \pm 1.90 \mathrm{bc}$ \\
\hline$[\mathrm{S}] \mathrm{NC}-\mathrm{PHB}(0.50)$ & $28.75 \pm 5.15 a$ & $8.94 \pm 0.32 \mathrm{~cd}$ \\
\hline [S]NC-PCL(0.50) & $33.75 \pm 4.73 a$ & $6.98 \pm 0.83 d$ \\
\hline$[\mathrm{S}] \mathrm{NC}-\mathrm{PHB}(0.25)$ & $42.50 \pm 2.50 b$ & $7.31 \pm 0.63 d$ \\
\hline [S]NC-PCL(0.75) & $45.00 \pm 7.91 b$ & $10.87 \pm 1.81 \mathrm{c}$ \\
\hline Organic Neem & $56.25 \pm 5.15 b$ & $9.10 \pm 1.78 c d$ \\
\hline $\mathrm{F}$ & - & 12.46 \\
\hline$p$ & $<0.001$ & $<0.001$ \\
\hline [P]NC-PHB(0.25)-NC & $15.00 \pm 4.08 a$ & $43.14 \pm 3.37 a$ \\
\hline$[\mathrm{P}] \mathrm{NC}-\mathrm{PHB}(0.50)$ & $15.00 \pm 2.04 a$ & $40.72 \pm 2.34 a$ \\
\hline Water-control & $16.25 \pm 3.75 a$ & $46.09 \pm 11.74 a$ \\
\hline [P]NC-PCL(0.25)-NC & $16.25 \pm 3.23 a$ & $32.83 \pm 1.74 a b$ \\
\hline [P]NC-PHB(0.25) & $21.25 \pm 7.47 a$ & $24.52 \pm 0.72 b c$ \\
\hline [P]NC-PCL(0.25) & $22.50 \pm 4.33 a$ & $34.94 \pm 2.54 a b$ \\
\hline [P]NC-PHB(0.75) & $25.00 \pm 4.56 a$ & $43.22 \pm 2.03 a$ \\
\hline [P]NC-PCL(0.50) & $31.25 \pm 3.15 a$ & $29.47 \pm 1.72 a b$ \\
\hline [P]NC-PCL(0.75) & $37.50 \pm 7.50 a$ & $20.16 \pm 1.91 b c$ \\
\hline [P]NC-PCL(0.25)pva & $55.00 \pm 10.80 b$ & $32.81 \pm 3.64 a b$ \\
\hline Organic Neem & $86.25 \pm 3.15 c$ & $2.45 \pm 1.67 c$ \\
\hline $\mathrm{F}$ & - & 9.26 \\
\hline$p$ & $<0.001$ & $<0.001$ \\
\hline
\end{tabular}

* Means followed by the same letter do not differ significantly by the Tukey test $(p<0.05)$.

$[\mathrm{S}]=$ suspension, $\mathrm{NC}=$ nanocapsules, $\mathrm{PCL}=$ poly( $(\varepsilon$-caprolactone $), \mathrm{PHB}=$ poly $($ ß-hidroxibutirate $), \mathrm{NC}=$ negative control, $\mathrm{pva}=$ poly(vinyl alcohol).

Most of the formulations in suspension were more effective than the corresponding powder formulations, suggesting that the spray drying process may result in loss of effect or in delayed release kinetics. This probably resulted from adsorption of nanoparticles and free active compounds to the drying support that need to be desorbed before liberation, and there may be some loss in this process. Pohlmann et al. (2002) found that nanospheres of PCL suffered rearrangement during the spray-drying process, and this may have altered the efficiency of the nanoformulations with nanospheres. The only nanoformulation in powder which caused a greater effect as compared as the suspension was [P]NC-PCL(0.25)pva (Table 4). This could be the result of a reduced structural stability of nanocapsules when prepared with PVA instead of Tween ${ }^{\circledR} 80$, leading to a better release. 
Table 5: Mortality and weight ( \pm SE) of fall armyworm larvae fed since the first instar with corn leaves treated with neem nanoformulations in suspension (fourth bioassay) and in powder (fifth bioassay) after 10 days.

\begin{tabular}{|c|c|c|}
\hline Treatment & Mortality (\%)* & Weight (mg)* \\
\hline Water-control & $20.00 \pm 5.40 a$ & $52.47 \pm 2.01 a$ \\
\hline [S]NS-PCL(0.25)+PVA & $25.00 \pm 0.00 a$ & $13.57 \pm 2.30 c$ \\
\hline$[S] N S-P C L(0.25)$ & $42.50 \pm 7.22 b$ & $7.07 \pm 1.52 c$ \\
\hline$[S] N S-P C L(0.50)$ & $40.00 \pm 5.40 b$ & $13.27 \pm 2.96 c$ \\
\hline$[S] N S-P C L(0.75)$ & $41.25 \pm 3.75 b$ & $10.48 \pm 0.72 c$ \\
\hline$[\mathrm{S}] \mathrm{NS}-\mathrm{PHB}(0.25)$ & $56.25 \pm 5.54 b$ & $7.44 \pm 0.42 c$ \\
\hline$[\mathrm{S}] \mathrm{NS}-\mathrm{PHB}(0.50)$ & $53.75 \pm 6.25 b$ & $7.57 \pm 1.36 c$ \\
\hline$[\mathrm{S}] \mathrm{NS}-\mathrm{PHB}(0.75)$ & $28.75 \pm 6.88 a$ & $15.19 \pm 1.79 b$ \\
\hline$[S] N S-P C L(0.25)-N C$ & $26.25 \pm 4.27 a$ & $61.90 \pm 4.35 a$ \\
\hline$[\mathrm{S}] \mathrm{NS}-\mathrm{PHB}(0.25)-\mathrm{NC}$ & $18.75 \pm 5.54 a$ & $50.62 \pm 10.81 a$ \\
\hline Organic Neem & $86.25 \pm 3.15 c$ & $8.13 \pm 3.71 c$ \\
\hline $\mathrm{F}$ & - & 11.81 \\
\hline$p$ & $<0.001$ & $<0.001$ \\
\hline Water-control & $20.00 \pm 0.00 a$ & $14.92 \pm 3.20$ \\
\hline [P]NS-PCL(0.25)+PVA & $27.50 \pm 3.23 a$ & $5.55 \pm 0.61$ \\
\hline [P]NS-PCL(0.25) & $20.00 \pm 2.04 a$ & $13.81 \pm 0.70$ \\
\hline [P]NS-PCL(0.50) & $28.75 \pm 2.39 a$ & $6.07 \pm 0.94$ \\
\hline [P]NS-PCL(0.75) & $20.00 \pm 2.04 a$ & $11.53 \pm 0.64$ \\
\hline$[\mathrm{P}] \mathrm{NS}-\mathrm{PHB}(0.25)$ & $20.00 \pm 2.04 a$ & $12.76 \pm 1.37$ \\
\hline$[\mathrm{P}] \mathrm{NS}-\mathrm{PHB}(0.50)$ & $22.50 \pm 3.23 a$ & $10.17 \pm 1.61$ \\
\hline$[\mathrm{P}] \mathrm{NS}-\mathrm{PHB}(0.75)$ & $26.25 \pm 2.39 a$ & $13.06 \pm 1.73$ \\
\hline [P]NS-PCL(0.25)-NC & $18.75 \pm 2.39 a$ & $11.47 \pm 4.96$ \\
\hline [P]NS-PHB(0.25)-NC & $21.25 \pm 2.39 a$ & $10.67 \pm 0.51$ \\
\hline Organic Neem & $100.00 \pm 0.00 b$ & --- \\
\hline $\mathrm{F}$ & - & 2.134 \\
\hline $\mathrm{p}$ & $<0.001$ & 0.058 \\
\hline
\end{tabular}

* Means followed by the same letter did not differ significantly by the Tukey test $(p<0.05)$.

$[\mathrm{S}]=$ suspension, $\mathrm{NS}=$ nanospheres, $\mathrm{PCL}=\operatorname{poly}(\varepsilon$-caprolactone $), \mathrm{PHB}=$ poly( (ß-hidroxibutirate), $\mathrm{NC}=$ negative control, $\mathrm{pva}=$ poly(vinyl alcohol).

The fact that some nanoformulations presented low or no efficiency may be due to the low degradation rate of the polymers during the evaluation period, resulting in little or no release of neem from the nanoparticles. The nanoparticles required humidity and/or microbial enzymatic activity in order to degrade the biopolymer and release the active principle (Costa et al., 2014). Moreover, not all of the neem oil/extract was encapsulated. Some neem remained free in the formulation, causing an initial insecticidal effect before release of the compounds by nanoparticles.

After correction for water-control mortality in each bioassay (Abbott, 1925), the four nanoformulations with higher control efficiency were $[\mathrm{P}] \mathrm{NC}-\mathrm{PCL}(0.25)+\mathrm{PVA}$ 
(46.01\%); [S]NS-PHB (0.25) (43.79\%); [S]NS-PHB (0.50) (42.77\%), and [S]NC-PMMA (0.25) (41.53\%), which were selected for residual effect and feeding preference tests.

\section{Residual effect and feeding preference}

None of the nanoformulations maintained its effect over time. In the residual effect bioassay starting at $1 \mathrm{DAS}$, all treatments differed from the water-control regarding mortality and larval weight after 10 days (11.67\% and $52.01 \mathrm{mg}$, respectively), highlighting [S] NS-PHB(0.25) $(76.67 \%$ and $3.30 \mathrm{mg})$, which was as efficient as Organic Neem $(88.33 \%$ and $3.00 \mathrm{mg})$. At 3 DAS, only [P]NC-PCL(0.25)pva lost efficacy, causing no mortality or weight reduction, but none of the other three nanoformulations had the same efficacy as Organic Neem. At 7 DAS, regarding mortality, only Organic Neem was effective $(38.33 \%)$ in relation to the control $(13.33 \%)$, while the nanoformulations did not differ from the control nor from the Organic Neem. However, [S]NS$\operatorname{PHB}(0.25),[\mathrm{S}] \mathrm{NS}-\mathrm{PHB}(0.50)$ and $[\mathrm{S}] \mathrm{NC}-\mathrm{PMMA}(0.25)$ still caused sublethal effects, characterized by low larval weight (Table 6 and 7).

Table 6: Mortality $( \pm S E)$ of fall armyworm larvae fed since the first instar with corn leaves treated with neem nanoformulations, after 10 days, starting at 1, 3 and 7 days after spraying, for residual effect evaluation.

\begin{tabular}{cccc}
\hline \multirow{2}{*}{ Treatment } & \multicolumn{3}{c}{ Mortality (\%)* } \\
\cline { 2 - 4 } & 1 DAS & 3 DAS & 7 DAS \\
\hline Water-control & $11.67 \pm 3.19 \mathrm{a}$ & $15.00 \pm 1.67 \mathrm{a}$ & $13.33 \pm 2.72 \mathrm{a}$ \\
[P]NC-PCL(0.25)pva & $46.67 \pm 7.20 \mathrm{~b}$ & $23.33 \pm 3.33 \mathrm{ab}$ & $15.00 \pm 3.19 \mathrm{ab}$ \\
[S]NS-PHB(0.25) & $76.67 \pm 3.33 \mathrm{c}$ & $40.00 \pm 8.61 \mathrm{bc}$ & $20.00 \pm 4.71 \mathrm{ab}$ \\
[S]NC-PMMA(0.25) & $40.00 \pm 7.20 \mathrm{~b}$ & $53.33 \pm 7.20 \mathrm{c}$ & $20.00 \pm 2.72 \mathrm{ab}$ \\
[S]NS-PHB(0.50) & $50.00 \pm 1.92 \mathrm{~b}$ & $43.33 \pm 10.36 \mathrm{bc}$ & $26.67 \pm 4.71 \mathrm{ab}$ \\
Organic Neem & $88.33 \pm 3.19 \mathrm{c}$ & $80.00 \pm 7.20 \mathrm{~d}$ & $38.33 \pm 8.33 \mathrm{~b}$ \\
\hline $\mathrm{p}$ & $<0.001$ & $<0.001$ & 0.016 \\
\hline
\end{tabular}

* Means followed by the same letter in the column did not differ significantly by the Tukey test $(p<0.05)$. DAS = days after spraying, $[\mathrm{S}]=$ suspension, $[\mathrm{P}]=$ powder, $\mathrm{NC}=$ nanocapsules, $\mathrm{NS}=$ nanospheres, $\mathrm{PCL}=\operatorname{poly}(\varepsilon$-caprolactone $), \mathrm{PHB}=\operatorname{poly}(\boldsymbol{B}-$ hidroxibutirate), PMMA = poly(methyl methacrylate), pva = poly(vinyl alcohol).

Table 7: Mean weight $( \pm \mathrm{SE})$ of fall armyworm larvae fed since the first instar with corn leaves treated with neem nanoformulations, after 10 days, starting at 1, 3 and 7 days after spraying, for residual effect evaluation.

\begin{tabular}{cccc}
\hline \multirow{2}{*}{ Treatment } & \multicolumn{3}{c}{ Weight $(\mathrm{mg})^{*}$} \\
\cline { 2 - 4 } & $1 \mathrm{DAS}$ & $3 \mathrm{DAS}$ & $7 \mathrm{DAS}$ \\
\hline Water-control & $52.01 \pm 4.14 \mathrm{a}$ & $54.78 \pm 2.98 \mathrm{a}$ & $68.95 \pm 2.79 \mathrm{a}$ \\
{$[\mathrm{P}] \mathrm{N} C-P C L(0.25)$ pva } & $13.86 \pm 1.83 \mathrm{~b}$ & $49.12 \pm 5.60 \mathrm{a}$ & $67.73 \pm 6.93 \mathrm{a}$ \\
{$[\mathrm{S}] \mathrm{NS}-\mathrm{PHB}(0.25)$} & $3.30 \pm 0.53 \mathrm{~d}$ & $8.72 \pm 0.78 \mathrm{~b}$ & $15.51 \pm 1.81 \mathrm{c}$ \\
{$[\mathrm{S}] \mathrm{NC}-\mathrm{PMMA}(0.25)$} & $5.85 \pm 0.52 \mathrm{c}$ & $8.57 \pm 0.79 \mathrm{~b}$ & $32.30 \pm 2.75 \mathrm{~b}$ \\
[S]NS-PHB(0.50) & $7.98 \pm 1.15 \mathrm{bc}$ & $12.89 \pm 1.31 \mathrm{~b}$ & $37.48 \pm 3.36 \mathrm{~b}$ \\
Organic Neem & $3.00 \pm 0.43 \mathrm{~d}$ & $3.74 \pm 0.29 \mathrm{c}$ & $9.49 \pm 1.71 \mathrm{c}$ \\
\hline $\mathrm{F}$ & 28.74 & 24.70 & 47.38 \\
$\mathrm{p}$ & $<0.001$ & $<0.001$ & $<0.001$
\end{tabular}

* Means followed by the same letter in the column did not differ significantly by the Tukey test $(p<0.05)$. DAS $=$ days after spraying, $[\mathrm{S}]=$ suspension, $[\mathrm{P}]=$ powder, $\mathrm{NC}=$ nanocapsules, $\mathrm{NS}=$ nanospheres, $\mathrm{PCL}=$ poly( $(\varepsilon$-caprolactone $), \mathrm{PHB}=\operatorname{poly}(\mathrm{B}$ hidroxibutirate), PMMA = poly(methyl methacrylate), pva = poly(vinyl alcohol). 
In the feeding preference test (Table 8), at 1 DAS leaves treated with nanoformulations [P]NC-PCL (0.25) pva, [S]NS-PHB (0.25), and the commercial neem oil were less eaten by the larvae than the control leaves. At 3 and 7 DAS, there was no difference in consumption with any of the treatments compared to the control. Based on the preference index values calculated, all treatments caused phagodeterrency at 1 DAS. At 3 DAS the commercial neem oil, [S]NC-PMMA (0.25) and [S]NS-PHB $(0.25)$ were phagodeterrents, and at 7 DAS all nanoformulations were neutral or near-neutral. Only Organic Neem still showed $\mathrm{PI}<1$, but higher than at 1 DAS, indicating that the phagodeterrent effect decreased.

According to Schmutterer (1990), the residual effect of neem-based products lasts for 5 to 7 days. Stokes and Redfern (1982) reported that the action of azadirachtin on fall armyworm after exposure to sunlight in the field was reduced around $80 \%$ after 3 days and by $50 \%$ after 7 days. In the present study, Organic Neem caused $80 \%$ mortality 3 days after spraying and $38.33 \%$ after 7 days. Caboni et al. (2002) observed a $90 \%$ reduction in the amount of azadirachtin found in treated olive trees under field conditions after 3 days, and after 7 days no residue was found. This occurs because azadirachtin and related compounds undergo very rapid degradation. Caboni et al. (2006) extracted some limonoids from methanolic extracts of neem seeds and exposed them to sunlight; the halflives calculated for azadirachtin, 3-tigloylazadirachtol, nimbin and salanin were $11.34,5.52,0.30$ and 0.09 hours, respectively.

Table 8: Consumed leaf area ( \pm SE) and preference index (after 24 hours) of fall armyworm third instars in dual choice tests with corn leaf disks either treated or untreated with neem nanoformulations, at 1, 3 and 7 days after spraying.

\begin{tabular}{|c|c|c|c|c|c|}
\hline \multirow{2}{*}{ Treatment } & \multicolumn{2}{|c|}{ Consumed Leaf Area $( \pm \mathrm{SE})^{\star}$} & \multirow{2}{*}{$\mathrm{F}$} & \multirow{2}{*}{$\mathrm{p}$} & \multirow{2}{*}{$\mathrm{Pl} * *$} \\
\hline & Treatment & Control & & & \\
\hline \multicolumn{6}{|l|}{$1 \mathrm{DAS}$} \\
\hline [P]NC-PCL(0.25)pva & $2.28 \pm 0.32 b$ & $3.67 \pm 0.40 a$ & 7.51 & 0.009 & 0.77 \\
\hline [S]NS-PHB(0.25) & $2.27 \pm 0.30 \mathrm{~b}$ & $3.62 \pm 0.30 a$ & 9.76 & 0.004 & 0.77 \\
\hline [S]NC-PMMA(0.25) & $2.51 \pm 0.29 a$ & $3.29 \pm 0.38 a$ & 2.61 & 0.114 & 0.87 \\
\hline$[S] N S-P H B(0.50)$ & $2.35 \pm 0.39 a$ & $3.49 \pm 0.42 a$ & 3.82 & 0.059 & 0.80 \\
\hline Organic Neem & $1.75 \pm 0.37 b$ & $4.14 \pm 0.47 a$ & 13.48 & $<0.001$ & 0.59 \\
\hline \multicolumn{6}{|l|}{3 DAS } \\
\hline [P]NC-PCL(0.25)pva & $5.90 \pm 0.63 a$ & $5.81 \pm 0.70 a$ & 0.01 & 0.907 & 1.01 \\
\hline [S]NS-PHB(0.25) & $2.99 \pm 0.63 a$ & $4.37 \pm 0.78 a$ & 1.87 & 0.179 & 0.81 \\
\hline [S]NC-PMMA(0.25) & $2.38 \pm 0.49 a$ & $3.06 \pm 0.63 a$ & 0.72 & 0.389 & 0.88 \\
\hline$[S] N S-P H B(0.50)$ & $2.60 \pm 0.56 \mathrm{a}$ & $1.76 \pm 0.39 a$ & 0.03 & 0.866 & 1.03 \\
\hline Organic Neem & $1.78 \pm 0.47 \mathrm{a}$ & $2.18 \pm 0.44 a$ & 0.37 & 0.548 & 0.90 \\
\hline \multicolumn{6}{|l|}{7 DAS } \\
\hline [P]NC-PCL(0.25)pva & $2.42 \pm 0.63 a$ & $2.35 \pm 0.52 a$ & 0.01 & 0.932 & 1.01 \\
\hline [S]NS-PHB(0.25) & $2.36 \pm 0.50 \mathrm{a}$ & $1.41 \pm 0.41 a$ & 2.10 & 0.156 & 1.25 \\
\hline [S]NC-PMMA(0.25) & $2.51 \pm 0.53 a$ & $1.84 \pm 0.56 a$ & 0.72 & 0.402 & 1.15 \\
\hline [S]NS-PHB(0.50) & $2.07 \pm 0.43 a$ & $2.20 \pm 0.52 a$ & 0.04 & 0,849 & 0.97 \\
\hline Organic Neem & $1.94 \pm 0.54 \mathrm{a}$ & $3.01 \pm 0.52 a$ & 0.47 & 0.497 & 0.89 \\
\hline
\end{tabular}

* Means followed by the same letter in the column did not differ significantly by the Tukey test $(p<0.05)$. ** Preference Index, DAS = days after spraying, $[S]=$ suspension, $[\mathrm{P}]=$ powder, NC = nanocapsules, NS = nanospheres, $\mathrm{PCL}=\operatorname{poly}(\varepsilon-\mathrm{caprolactone})$, $\mathrm{PHB}=$ poly $($ ß-hidroxibutirate), $\mathrm{PMMA}=$ poly(methyl methacrylate), pva = poly(vinyl alcohol). 
Ourbioassays showed that the effect of neem was neither maintained nor increased over time with nanoformulations. Forim, Silva and Fernandes (2011) found that the nanoparticle production process did not affect azadirachtin's stability. Ultraviolet stability assays showed that encapsulated azadirachtin was more stable than the unencapsulated form. This enhances the possibility that the effect caused by neem nanoformulations was due to the neem that remained free in the formulations (not encapsulated), causing an immediate effect on the larvae. In fact, the nanocapsules and nanospheres bioassayed in this work showed average nanoencapsulation efficiencies of 68 and 33\%, respectively. After ceasing the effect of the free azadirachtin, due to degradation, there was no action of the encapsulated compounds, probably because there was either very little or no release by the nanoparticles during the evaluation period. Plants treated with the nanoformulations were kept in a greenhouse, so it is possible that the conditions of this environment were unfavorable to degradation of the polymers. Field studies could provide a better assessment of the performance of the nanoformulations.

\section{CONCLUSIONS}

Although the polymers and other components used have proven effective for the production of nanoparticles containing neem, not all of the nanoformulations obtained showed insect control efficiency and none showed a high residual effect, indicating that there was little or no liberation by the nanoparticles. Further studies are needed to improve the release rate of the azadirachtin by the polymers.

\section{ACKNOWLEDGEMENTS}

The authors thank Fundação de Amparo à Pesquisa do Estado de São Paulo (FAPESP, Proc. No. 2005/60040-0, No. 2007/53395-1) and Conselho Nacional de Desenvolvimento Científico e Tecnológico (CNPq) for their financial support.

\section{REFERENCES}

ABBOTT, W. S. A method of computing the effectiveness of an insecticide. Journal of Economic Entomology, 18:265$266,1925$.

BURTON, R. L.; PERKINS, W. D. WSB, a new laboratory diet for the corn earworm and the fall armyworm. Journal of Economic Entomology, 65(2):385-386, 1972.

CABONI, P. et al. Persistence of azadirachtin residues on olives alter field treatment. Journal of Agriculture and Food Chemistry, 50:3491-3494, 2002.
CABONI, P. et al. Residues and persistence of neem formulations on strawberry after field treatment. Journal of Agriculture and Food Chemistry, 54:10026-10032. 2006.

CAMPOS, A. P.; BOIÇA JUNIOR, A. L. Lagartas dc Spodoptera frugiperda (J. E. Smith) (Lepidoptera: Noctuidae) submetidas a diferentes concentrações de óleo de nim. Revista Brasileira de Milho e Sorgo, 11(2):137-144, 2012.

CHAN, A. S. et al. Evaluation of silica sol-gel microcapsule for the controlled release of insect repellent, N,N-diethyl-2methoxybenzamide, on cotton. Philippine Journal of Science, 138(1):13-21, 2009.

CORREIA, A. A. et al. Morfologia do canal alimentar de lagartas de Spodoptera frugiperda (J.E. Smith) (Lepidoptera: Noctuidae) alimentadas com folhas tratadas com nim. Neotropical Entomology, 38(1):829-837, 2009.

COSTA, J. T. et al. Effects of different formulations of neem oilbased products on control Zabrotes subfasciatus (Boheman, 1833) (Coleoptera: Bruchidae) on beans. Journal of Stored Products Research, 56:49-53, 2014.

CRUZ, I.; MONTEIRO, M. A. R. Controle biológico da lagarta do cartucho do milho, spodoptera frugiperda, utilizando o parasitóide Trichogramma pretiosum. Sete Lagoas: EMBRAPACNPMS, 2004. 4 p. (EMBRAPA-CNPMS. Comunicado técnico, 98).

DAS, R. K. et al. Nanoformulation of insecticides: novel products. Biofertilizants and Biopesticides, 5(1):2, 2014.

FESSI, H. et al. Nanocapsule formation by interfacial polymer deposition following solvent displacement. International Journal of Pharmaceutics, 55(1):1-4, 1989.

FINNEY, D. J. Probit analysis. Cambridge: Cambridge University Press, 1971. 255p.

FORIM, M. R. et al. Uso de CLAE no controle de qualidade em produtos comerciais de nim: reprodutibilidade da ação inseticida. Química Nova, 33(5):1082-1087, 2010.

FORIM M. R.; SILVA M. F. G. F.; FERNANDES, J. B. Secondary metabolism as a measure of efficacy of botanical extracts: the use of Azadirachta indica (Neem) as a model. In: PERVEEN, F. Insecticides - Advances in Integrated Pest Management. Rijeka: InTech, 2011. p.367-390.

ISMAN, M. B. Botanical insecticides, deterrents, and repellents in modern agriculture and an increasingly regulated world. Annual Review of Entomology, 51:45-66, 2006.

KOGAN, M.; GOEDEN, R. D. The host-plant range of Lema trilineata daturaphila (Coleoptera: Chrysomelidae). Annals of Entomological Society of America, 63:1175-1180, 1970. 
LEORA SOFTWARE. Poloplus $\mathbf{1 . 0}$ probit and logit analysis. Berkeley, 2003. 1 CD-ROM.

LIMA, M. P. L. et al. Bioatividade de formulações de nim (Azadirachta indica A. Juss, 1797) e de Bacillus thuringiensis subsp. aizawai em lagartas de Spodoptera frugiperda (J.E. Smith) (Lepidoptera: Noctuidae). Ciência e Agrotecnologia, 34(6):1381-1389, 2010.

$\mathrm{LI}, \mathrm{J}$. et al. Controlled release and retarded leaching of pesticides by encapsulating in carboxymethyl chitosan /bentonite composite gel. Journal of Environmental Science and Health, 47(8):795-803, 2012.

MORDUE (LUNTZ), A. J.; BLACKWELL, A. Azadirachtin: an update. Journal of Insect Physiology, 39(11):903-924, 1993.

MORDUE (LUNTZ), A. J.; NISBET, A. J. Azadirachtin from the neem tree Azadirachta indica: its action against insects. Anais da Sociedade Entomológica do Brasil, 29(4):615632, 2000.

OLIVEIRA, J. L. et al. Application of nanotechnology for the encapsulation of botanical insecticides for sustainable agriculture: Prospects and promises. Biotechnology Advances, 32:1550-1561, 2014.

PERLATTI, B. et al. Polymeric nanoparticle-based insecticides: a controlled release purpose for agrochemicals. In: TRDAN, S. (Ed.) Insecticides - Development of Safer and More Effective Technologies. Rijeka: InTech, 2013. p.524-550.

POHLMANN, A. R. et al. Spray-dried indomethacinloaded polyester nanocapsules and nanospheres: development, stability evaluation and nanostructure models. European Journal of Pharmaceutical Sciences, 16:305-312, 2002.

R DEVELOPMENT CORE TEAM. R: A language and environment for statistical computing. R Foundation for Statistical Computing, Vienna, Austria, 2009. Available in:<http:// www.R-project.org>. Access in: Jul. 12, 2015.
RAMPELOTTI FERREIRA, F. T.; VENDRAMIM, J. D.; FORIM, M. R. Bioatividade de nanoformulações de nim sobre a traça-dotomateiro. Ciência Rural, 42(8):1347-1353, 2012.

RÉ, M. I.; RODRIGUES, M. F. A. Polímeros biodegradáveis. In: DURÁN, N.; MATTOSO, L. H. C.; MORAIS, P. C. Nanotecnologia: introdução, preparação e caracterização de nanomateriais e exemplos de aplicação. São Paulo: Artliber Editora, 2006. p.149-160.

RIYAJAN, S.; SAKDAPIPANICH, J. T. Development of a controlled release neem capsule with a sodium alginate matrix, crosslinked by glutaraldehyde and coated with natural rubber. Polymer Bulletin, Berlin, 2009. Available in: <http:// www.springerlink.com/content/b6661941kq293859>. Access in: Jul. 20, 2015.

ROEL, A. R. et al. The effect of sub-lethal doses of Azadirachta indica (Meliaceae) oil on the midgut of Spodoptera frugiperda (Lepidoptera, Noctuidae). Revista Brasileira de Entomologia, 54(3):505-510, 2010.

ROSA, D. S.; PENTEADO, D. F.; CALIL, M. R. Propriedades térmicas e biodegradabilidade de PCL e PHB em um pool de fungos. Revista de Ciência e Tecnologia, 15:75-80, 2000.

SCHMUTTERER, H. Properties and potential of natural pesticides from the neem tree, Azadirachta indica. Annual Review of Entomology, 35:71-297, 1990.

STOKES, J. B.; REDFERN, R. E. Effect of sunlight on azadirachtin: antifeeding potency. Journal of Environmental Science and Health, Part A, 17(1):57-65, 1982.

VIANA, P. A.; PRATES, H. T.; RIBEIRO, P. E. A. Efeito de extratos de nim e de métodos de aplicação sobre o dano foliar e o desenvolvimento da lagarta-do-cartucho, Spodoptera frugiperda, em milho. Revista Brasileira de Milho e Sorgo, 6(1):17-25, 2007.

YEO, I.; JOHNSON, R. A new family of power transformations to improve normality or symmetry. Biometrika, 87:954959, 2000. 